International Journal of Instruction e-ISSN: 1308-1470 • www.e-iji.net
July $2020 \bullet$ Vol.13, No.3

p-ISSN: 1694-609X

pp. $805-826$

Received: $28 / 07 / 2019$

Revision: 06/03/2020

Accepted: 19/03/2020

OnlineFirst:24/05/2020

\title{
Learning Decision and Spiritual Based Skills for Adult Education
}

\section{Elfi Mu'awanah}

Assoc. Prof., IAIN Tulungagung, Indonesia, elfi_muawanah@yahoo.co.id

\section{Nur Hidayah}

Prof., State Universitas Negeri Malang, Indonesia, nurhidayah.fip@um.ac.id

\section{Sulistyorini}

Assoc. Prof., IAIN Tulungagung, Indonesia, sulistyorini@iain-tulungagung.ac.id

\section{Rifa Hidayah}

Assoc. Prof., UIN Maulana Malik Ibrahim Malang, Indonesia, rifa_hidayah@psi.uinmalang

\begin{abstract}
The study was conducted on adult women who would run for village head. Because education is provided through adult learning in taking decisions and accompanied by spiritual guidance, adult educations were also required to increase college services to enter the community. The question researches were how women as candidate village head can make decision to become a village head and how to implemented spiritual guidance counselling for politic (SGCP) among adult women education toward political decision making. With one subject, mix method for single subject design of this research, found strengthening woman as adult education more strong to make decision and become a winner as head viillage. Spiritual guidance counselling for politic (SGCP) was a construct of educational psychology for woman in preparing and facing politic. The aim of SGCP became a first SGCP provided by the candidate of village head as one of the representative candidates reinforce the woman in decision making to be the contestant of woman head the village. The second prepare, the woman as the woman representative and face the risk of candidacy after successfully being a village head or not. Being the contestant of woman's representation needs such four things as gender, people, financial, prays, spiritual.
\end{abstract}

Keywords: adult education, desicion making, SGCP, learning, spiritual based skills

\section{INTRODUCTION}

The equality of opportunity between male and female to participate in the decision making and policy determination was the prerequisite of the democracy function. The policy-making was the process of decision making was derived from internal and

Citation: Mu'awanah, E., Hidayah, N., Sulistyorini, \& Hidayah, R. (2020). Learning Decision and Spiritual Based Skills for Adult Education. International Journal of Instruction, 13(3), 805-826. https://doi.org/10.29333/iji.2020.13354a 
external factors for example, value, knowledge/information, education, intelligence, talent, passion, characteristic, and physical condition. Meanwhile, the external factors were such as TV/mass media, people, social-economic condition, the social-economic status, the influence of family member, friend-interaction, and educational level-skill (Bullough, et. al, 2012). Women's political representatives who need skills to master political skills and political applications for themselves. When a decision has been taken, all factors of risk would be personal responsibility (Nobles, et.al, 2010).

Based on the facts in the field, there were some female political representative candidates who were failed to be the political representative underwent the trauma due to the lack of mentoring of spiritual guidance and counselling of woman's politic. Some facts show that there was a family that brought the failed legislative member candidate to the Rehab of Mental and Soul in Jakarta. There was a candidate's recognition that she had spent 100million rupiahs in Purbalingga. However, she was not selected as the legislative member. They were sad, angry, and stressful so that they did many things such as stealing the voting box, blocking the settlement even they did suicide in Sampang and Banjar cities. There was also a candidate that was failed to be elected as the legislative member took again her donation for the mosque, mushola, and learning place in a Kindergarten in Tulungagung. In Cirebon, a candidate was failed and he was medically treated by reading Quran verses for her since she had lost 300 million and could not control herself. That was the risk factor of someone's choice when he/she nominates him/herself to be a political representative. The risk was that when they win they would be happy, but they did not prepare the risk of losing so that they got trouble.

Based on the importance of preparing themselves in the village head election, the researcher formulated the research questions as follows.

(1) How women as candidate village head can make decision to become a village head?

(2) How to implemented spiritual guidance counselling for politic (SGCP) among women adult education toward political decision making?

The purpose of this research is how SGCP effort can help a female makes decision to become village head candidate and how the process of winning elections in the village by a village head representative of the female sex.

\section{LITERATURE REVIEW}

\section{Adult Education}

Adult education directs a person to think critically, reflectively, pay attention to the social environment and movement, professionally, hold all the potentials and potentials that are around adult education (Zeuner, 2017). This means that adult education is education given to someone to enter the climate of work of certain career stabilization and even career advancement opportunities. Independence in decision making in all aspects of life is the miracle thing.

Figure 1 directing the goals of adult education (Yang, 2016) and someone can use one of the theories or a compilation of all three when someone wants to provide for adults where the orientation each course is different (Rogers, 2017), providing for 
development of generating projects, and friendship. There are programs from government, NGOs and self-help groups for intergenerational learning. There were suggestions for adult education to develop educational policies, a part from other related social policy initiatives. In some countries as Figure 1 is funded by the public and the emergence of European adult education invited the presence of necessity to organize activities that support and apply at the nation. The existence of human resources, economic conditions, and the need for an organization that cares about the emergence and growth of family income are the strengths of adult education (Weiterbildung, 2018). Adult education was also given quality. Even in Ireland, Dublin City, LangfordWestmeath and Cavan Monaghan adult education was centered in the city center and assessment is provided for adult education (Weiterbildung, 2018). Adult education is part of the work in the field of education, therefore its implementation is funded by that field. In Italy adult education is directed primarily at economic empowerment. In Serbia, adult education is directed at eradicating illiteracy, increasing requirements for employment, economic and social and the existence of state policies regarding learning anytime with anyone in any way.

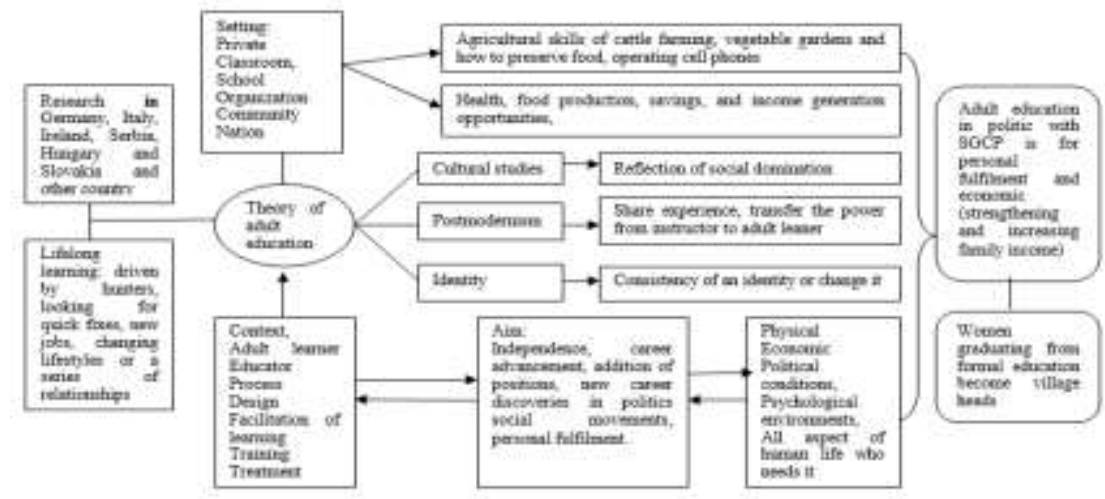

Figure 1

Overview on Adult Education and It Relevance with Research

In Slovakia, there is an adult education policy that is part of national education so there is a lifelong learning strategy implemented in the country. Synthesis of 21 regions surveyed by Ireland, Serbia and Slovakia makes adult education a part of national and state education. German education becomes a part of regional education. Italy provides overall oversight and confirmation for adult education policies and goals related to economic and social employment objectives. In Serbia, adult education is directed at reducing the amount obtained, capital letters, and cultural, social and economic interests. Likewise, UNESCO has an impact on CONFINTEA in the global context (Milana \& York, 2017) and the organization also influences OECD. Brazil, Argentina, the United States and Italy bring up adult education associated collaborate with several parties to increase employment opportunities as lifestyles (Formenti, et.al, 2018). The nature of adult education is andragogy method contains the principles of voluntary, autonomous, contributing, inspired likes in Tanzania learners (Ali, et. al 2009). 


\section{Learning Decision Making}

One need to learn to make decisions, to avoid mistakes in taking action (Bruniges, 2007). Especially if the decision taken was related to welfare, additional income or fortune and what life needs to be prepared should be carefully prepared and calculated by adult students. Learning decisions need knowledge - both knowledge in skills, the finesse to assess and meet the necessity of expression, build individual abilities, open self, heart, mind to all existing knowledge, asking for open, responsible work, consistency, comparability (Frazeur \& Michael, 2013) beside that finding the reason why the decision was made (Leigh, et. al, 2019) explore beliefs, self-efficacy, and race, knowledge, beliefs, potential, can be the basis for decision making. Reflections on experience, interests and knowledge are the drivers of decision making (Jiang, 2017). Skills, strategies and settlements in accordance with the decisions taken external and internal environmental factors, direct cues that exist in the environment, take action to interact effectively (Langdon, et.al, 2019), experience (Smith, 2017) and gaining respect from group members (Sundararajan \& Sheehan, 2013) framework, mindset, reality of life, depth of experience can accelerate decision making ( Nhi, et.al, 2019) emotional and aversive conditions also influences decisions (Yau \& Mcnally, 2019).

In decision making should notice the step that should be done regarding his/herself (Bruniges, 2007) starts from self-understanding, self-acceptance, decision making, and self-orientation based on the decision and then actualizing his/herself and understanding the risk factor of the taken decision. The mistake in decision making will result in the fault in taking the opportunity of the intended position/job. Thereby, someone who wants to achieve the position of village head should analyze his/her appropriateness and readiness toward self-potential, economic potential, spiritual readiness, and potential of people's support for him/her. So, Figure 2 is state of decision making in order to the decision maker did not made mistake in taking the opportinity of the intended position.

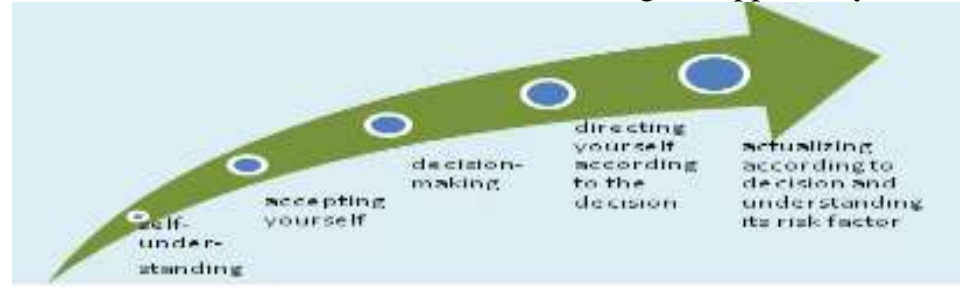

Figure 2

State of Decision Making (adaptation from Cremer, 2013)

When someone decides to do something, then it should quickly be able to decide what someone is doing. With all the risks that someone would accept, they should also be ready. To make decisions should be done quickly and correctly. Therefore, SGCP material also enhances adult education skills so that they were not wrong in making decisions and all actions can be directed to the decisions that have been taken. In understanding, accepting, making decisions in literature studies it was known that decision making was always associated with an activity taken by an individual. The most important thing that an individual need to do was making a decision at the right time and 
quickly. For example, if you want to become a village head, if it is not appropriate and quick to make a decision then you will be late in registering and other expectations or risks from the decision will be lost. For adult education, assisting major events that are passed in their lives is the right thing especially if the choice of decisions was related to the involvement of many people such as the election of village heads or political parties that involve many individuals to participate. SGCP was an adult education ingredient to be ready to face all the risks of decisions taken and prepare

\section{Decision Making in Politic for Women Representation}

There were two policies that should be run by the government namely: 1) increasing the woman's position and role in the life of nation and state through national policy done by an institution that could struggle for gender equality. 2) Improving the quality of role and independence of woman's organization by still maintaining the value of unity and integrity as well as the historical value of woman's struggle to continue the women empowerment and people's family prosperity (CEDAW and ICESCR). 2) Participation and political recruitment of woman, 3) the urgency of women in the general election was fulfilling the $30 \%$ of quota; the voters who give their aspiration to the women could raise the gender issue and find the strategy of fulfilling the gender issue (Koyuncu, 2016).

Most of the women in Pakistan choose to work out of their homes and they could include in the political job (Grünenfelder, 2013), opportunity (Pruysers \& Blais, 2014), could be shown in the female voter's education. But in Syria state, the violence happens to the women so that the woman's representation in the politic is urgently needed in politic to reduce the violence (Alsaba \& Kapilashrami, 2016). The violence to the women also happens in the other countries (Paudel \& Araujo, 2016). It required women's political representation (Spicer \& McGregor, 2017) when women include in politic, they should not be symbolic as happening in Belgian (Celis, 2013) as well as (Mendelberg, 2016) and the women's involvement in politic was expected could cover the gender disparity since sometimes the women have their own problems as occurring in North Korea (Jeong \& Kim, 2016). Moreover, the model of political education should be applied to realize the women's human rights especially political right (ICESCR) (Jacobs et.al, 2013) and challenge and opportunity for getting a good position for the women (Gârboni, 2014).

Almost all countries apply the quota of the woman. Turkey, for example, mentioned the significance of woman's political role (Koyuncu, 2016) and the needs of woman's human right could be more represented (Quamruzzaman \& Lange, 2016), (Ghani, \& Kerr, 2014). Indonesia, the Law of political Party number 2 of 2011 states about the political party: Meanwhile, according to (Gârboni, 2014) in Rumania reached 39\% and influenced the women's improvement in political field since the highest percentage of women in politics $(36 \%)$ was higher than Indonesia. The woman's political representation that expected could improve and the people's prosperity and the economy (York \& Bell, 2014) and it's change for empowering and educating the women (Karp, 2008). 


\section{Spiritual Guidance Counselling for Politic (SGCP) for the Success of Adult Education became the Village Head}

The reason SGCP data in the field in the area of Java, the seat of the village head, political parties and the governor was very rarely achieved by women. SGCP was an approach given accordance with the aim which's to succeed in his election to become the village head. Iinterventions' provided in the form of; 1) exploring and displaying the readiness of decision making and efforts to accept the risk of decisions that taken in relation to politics 2) connecting with the clerics if necessary wirid and tools to increase the love of voters to prospective village heads, 3) aware of the importance of gender, financial, people support, spiritual, praying as factors that need to be had if you someone wants to be the village head, 4) understand the verses of the Quran related to politics, and that when a person becomes the head of the village is when he has power, and power is a tool to uphold the teachings of the religion of God.

The mentors SGCP were researchers or author collaboration of counselling scientists, psychological scientist's education scientists based on Islamic religion, that conducted community training for adult learner and for all age's leaner. Then one of the strategies is that the candidate needs to prepare himself well 1) Gender, 2) financial, 3) people, 4) praying, and 5) spiritually. In term of the women who choose to include in politics and the spiritual counselling, the support needed is the correlation between theory of appreciative and theology of Christian implemented in Christian counselling to take the part of Godhead mystery (Sandu \& Caras, 2014). The impact of religious counselling on the female Iranian's spiritual happiness and prosperity who was suffered from cancer and randomly collected the spiritual advices for eight weeks (Sajadi, et.al, 2018) stated that psychosocial prosperity (Goetzmann, et.al, 2006) and the need of counselling during the procedure of evaluation of the result showed that women in politics. The political counselling to the woman's representation is giving the woman's political reinforcement through the verses of Quran about the politic as shown in Figure 3.

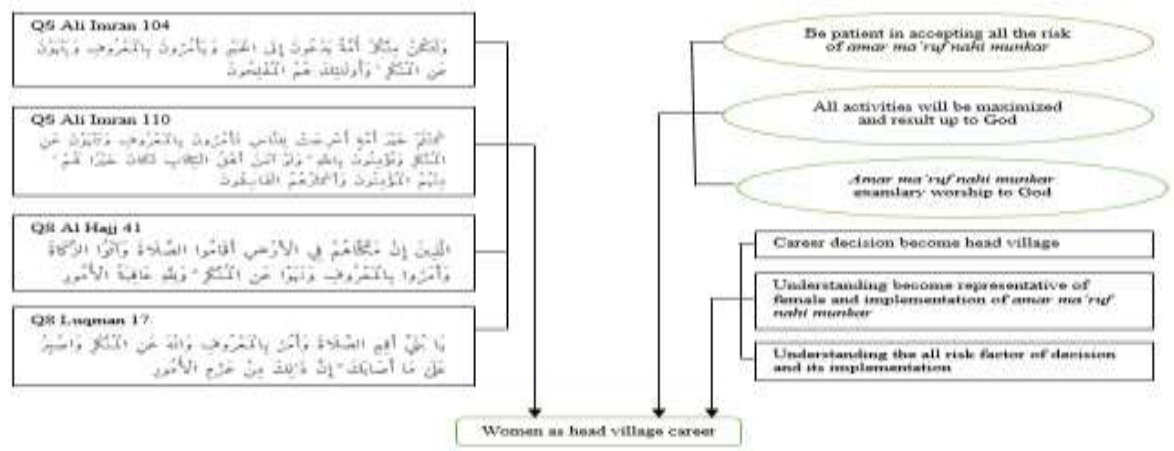

Figure 3

The Verse of Quran SGCP and Decision to be a Female Village Head Career

This research aimed to apply the spiritual counselling approach to the woman that were facing the period of general election of village head, analyse the readiness of independence potential of female representative in the government, the counselling of 
the decision to be the female representative and help to prepare the woman to the risk factor of the women to be a village head decided by themselves. and when someone has become the head of the village then Figure 3 becomes in carrying out the religious orders in the future government and what is of worship value.

\section{METHOD}

Qualitative research with inside lives the quality of biography of Campbell in reveals real personal experiences, can be seen in the daily facts of a person, completely reflected in the portrait of life. then from the expression of the facts of life, it is taken advantage of someone else to become an example and analytical material in line with the opinion of Campbell (Sherman, 2005). Since the village head is the woman's representation so the model of qualitative is biography qualitative. The research was then integrated in SGCP the process step. In other sides this research can be mixed methods involve community based stakeholders. Mixed methods also is a way to get an overview of research by optimizing quantitative and qualitative data, analysis and interpretation (Crewell, 2014), comparative methode (Creswell \& Wisdom, 2013) or (Ragin, 2014) or multi methode (Seawright, 2016) or multiphase design. This research is included in using quantitative and qualitative research methods to make a difference in this research are the adult education decision making phase and the change in adult education status phase from candidate to village head. Key stakeholders come from prospective village heads (women), which in the treatment stages also provide input or share experiences as a hallmark of adult education.

\section{Research Design}

The research design in this study can be called a single subject experimental design and named single case experiment design, which was a research design that measured the relationship between 2 or more variables. Single case experimental design was chosen because it had a picture that matches the characteristics of the study carried out by the researcher, as follows below. 1. There was a specific SGCP treatment goal. 2. Performed several measurements of the dependent variable in this case adult education: woman candidate head of village. 3. There was an SGCP treatment phase as shown in Table 2. and 4. Stability of the baseline data. The design type used in this study is type A-B-A design, where there were three experimental phases, namely phase A was the baseline phase and phase $B$ is the intervention phase. Phase $A$ is the measurement phase of woman adult education in chat 1 , which is the decision making and the election of the person concerned as the village head. While phase B is the phase of implementing interventions which in the form of research provides an understanding of the importance of decision making and its risks, concerning women's politics, the proposition of religion the importance of jihad when becoming a village head, and the ability to follow up spiritually using spiritual items.

Base line
(First conditions) $\underset{\text { Treatment }}{\overrightarrow{S G C P}} \underset{\text { (Final conditions) }}{\text { Base line }}$

Figure 4

Single Case Experimental Design (adaptation from Barlow \& Hersen, 1984) 
This experimental research was actually qualitative even though it used quantitative terms. This design wanted the researcher to show that there was a treatment to be the village head and that treatment was that the SGCP succeeded in delivering an adult education woman (as single subject) to become a village head. In the mix method research can be further refined data support and interpretation of the findings because in terms of quantitative and qualitative aspects (Seawright, 2016). Researchers use the method concurrent triangulation designs. collection of qualitative and quantitative data in research into material researchers to analyze alternately or complement each other so that research objectives can be achieved (Creswell, 2014).

\section{Research Subject}

Purposive sampling was choices in single case experimental design (Barlow \& Hersen, 1984). The characteristic of adult education of research subjects as Table 1 and the research subjects is 1 person.

Table 1

Characteristic of Adult Education of Research Subjects: 1 Person

\begin{tabular}{|c|c|c|}
\hline No & Aspect & Indication \\
\hline 1 & Education & graduate undergraduate education \\
\hline 2 & $\begin{array}{l}\text { Marital status and potential } \\
\text { supporting of family }\end{array}$ & $\begin{array}{l}\text { Married and having } 2 \text { children, her husband supporting fully her to become head of } \\
\text { village }\end{array}$ \\
\hline 3 & $\begin{array}{l}\text { Age when applying to be a } \\
\text { candidate for village head }\end{array}$ & $\begin{array}{l}35 \text { (mature age becomes the leader), based on the health check the female doctor was } \\
\text { declared healthy }\end{array}$ \\
\hline 4 & $\begin{array}{l}\text { The potential of social life } \\
\text { and leadership }\end{array}$ & $\begin{array}{l}\text { socially sociable, supple and Muslim women run an orderly prayer service five times } \\
\text { and attend religious activities and even these women gather social gatherings and invite } \\
\text { reading Yasin's letters every Thursday night, in terms of leading data can be obtained } \\
\text { that these women can educate their children well also lead community groups around } \\
\text { his residence well }\end{array}$ \\
\hline 5 & $\begin{array}{l}\text { The potential of social } \\
\text { economic }\end{array}$ & $\begin{array}{l}\text { socio-economic conditions of the subjects of this study already have the economic } \\
\text { capital of working and owning agricultural land to support themselves and their families }\end{array}$ \\
\hline
\end{tabular}

\section{The Instrument of SGCP were Conduct by Author}

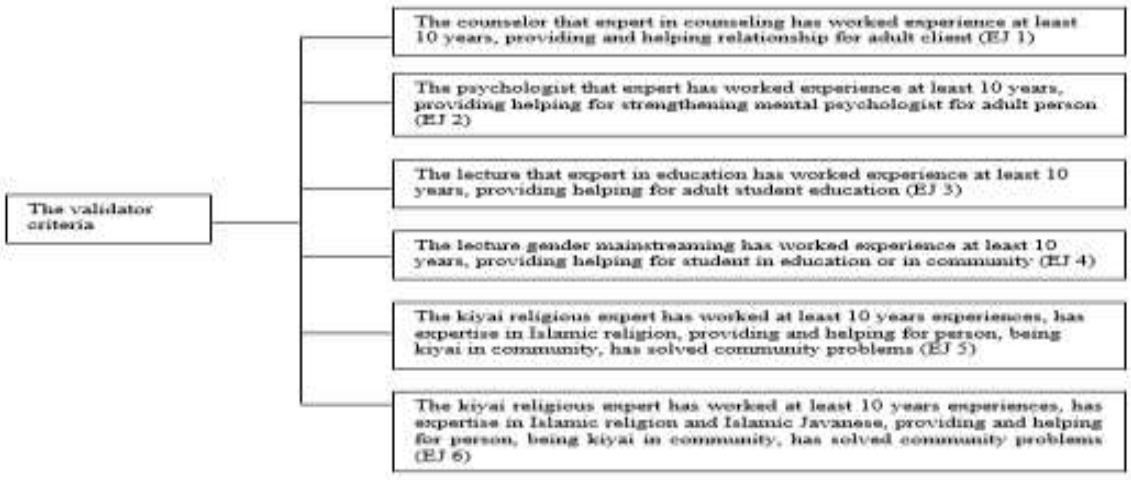

Figure 5

Criteria of Expert Judgment

SGCP's a treatment given to research subjects that contain decision making, challenges to the village, because women and religious representatives participate in spiritual 
activities. The content of SGCP was validate to expert judgment 6 persons according to the field of SGCP that given to assess the appropriateness of SGCP instruments. The criteria of experts judgment chosen are as follows : 1 person of counselor (Prof. Dr. Mungin Eddy Wibowo, M.Pd.,Kons), 1 person of psychologist (Dr. Sokip, M.Pd), 1 person of education expert (Prof.H. Ahmad Sonhadji K..H.,M.A, Ph.D) 1 person of gender expert (Dr. Naqiah, M.Ag) , 1 person of religious expert (Romo Kiyai Imam Sukadi), 1 person of spiritual expert (Romo Kiyai Ki. Abdus Shomad Very Eko Atmojo).

As for the treatment material provided to the subject in the form of decision making, political education, guidance, counseling, psychology, gender, religion, spiritual broadly, is as shown in Table 2.

Table 2

Instruments SGCP

\begin{tabular}{ll}
\hline Part of SGCP & Content treatment \\
\hline Leaning decision & Understanding the self-potential \\
& Acceptance \\
& $\begin{array}{l}\text { Self-orientation for decision } \\
\text { Self-actualization and understanding of the risk of decided choice } \\
\text { women's representation because no all woman can be chosen in politic career }\end{array}$ \\
& $\begin{array}{l}\text { Struggle in the path of religion as worship } \\
\text { Heads village fight for }\end{array}$ \\
& Kiyai have the wisdom of giving wired from their teachers follow ritual: \\
Spiritual: follow the beliefs of & keris, salt, rings are only tools, all destiny is determined by God \\
\hline
\end{tabular}

\section{Validation of Instrument SGCP}

To validate the treatment instrument, an expert test was conducted with the following results. Scoring aspects of the SGCP instrument between 10-100 with the breakdown of values as follows.

Table 3

The Result Instrument SGCP from Expert Judgement

\begin{tabular}{llllllll}
\hline No & Rated aspect & EJ 1 & EJ2 & EJ 3 & EJ4 & EJ5 & EJ6 \\
\hline 1 & Clarification of SGCP concept & 85 & 85 & 85 & 85 & 85 & 85 \\
2 & Clarification of SGCP treatment arguments & 91 & 92 & 92 & 92 & 92 & 92 \\
3 & Clarification of the formulation of the SGCP & 86 & 86 & 86 & 87 & 87 & 85 \\
& treatment objectives & & & & & & \\
4 & Clarification of treatment subject & 87 & 85 & 86 & 87 & 86 & 87 \\
5 & Systematic of treatment step & 87 & 85 & 85 & 85 & 86 & 86 \\
6 & Adherence to the SGCP technique & 87 & 87 & 87 & 87 & 88 & 86 \\
& Total score & 523 & 520 & 521 & 523 & 524 & 521 \\
& Mean & 87 & 86,7 & 86,8 & 87 & 87,3 & 86,8 \\
& X of Mean & $\mathbf{8 7}$ & & & & & \\
\hline
\end{tabular}

Note: $10-50=$ not feasible, $51-70=$ feasible, $71-100=$ very feasible

The average expert judgment is 87 on Table 3 , so the SGCP instrument's very feasible for be used as a treatment.

\section{Data Collection Techniques}

The technique in the mix method with sequential explanatory strategy's a strategy for researchers to combine data found from one of quantitative method (scoring or value) with another three method of qualitative (interview, observation, documentation) analysis and data exposure. 


\section{Interview}

Interviews to find out: 1. Condition of adult education before being given SGCP treatment of the relevant background and life history. 2. The results of treatment in the form of readiness to become village head and female representatives in the academic politics of students who experience learning during and after treatment.

\section{Scoring or Valuing}

The total reference of scoring or valuing achieved by subjects in research made by researchers to provide an assessment of behavioral changes that occur in this research subjects. As valuing quantitative for research subject condition during before and after treatment. The data collected is then entered in the following table, then analyzed and interpreted according to the purpose of the study.

Table 4

Value of Decision Making

\begin{tabular}{lll}
\hline Aspect of decision making & Score & Value category \\
\hline Understanding & $10-100$ & $10-50$ bad \\
The acceptance & $10-100$ & $51-70$ good \\
Decision making & $10-100$ & $71-100$ very good \\
Directing according decision making & $10-100$ & \\
Actualization decision and risk of decision & $10-100$ & \\
\hline
\end{tabular}

To provide scores before and after the SGCP treatment, the following is a measurement of behavioral change in research subjects. To provide scores before and after the SGCP treatment, the following is a measurement of behavioral changes of research.

Table 5

Scores before and after the SGCP treatment

\begin{tabular}{|c|c|c|c|c|}
\hline No & Indicator & Score & Before SGCP & After SGCP \\
\hline & Scoring of Understanding & & & \\
\hline 1 & Mentions self-strengths and directs self-strengths & $0-25$ & 16 & 23 \\
\hline 2 & Mentions self-deficiencies and ways to overcome self-deficiencies & $0-25$ & 15 & 23 \\
\hline 3 & Identify the goals that we want to achieve in life & $0-25$ & 15 & 23 \\
\hline \multirow[t]{3}{*}{4} & $\begin{array}{l}\text { Choosing the current goals to be achieved today is related to the opportunity to } \\
\text { become a village head }\end{array}$ & $0-25$ & 15 & 23 \\
\hline & Total scoring $/ \sum$ & 100 & 58 & 92 \\
\hline & Scoring of the Acceptance & & & \\
\hline 1 & $\begin{array}{l}\text { Grateful for their strengths to be channeled to things that meet the requirements to } \\
\text { become the village head }\end{array}$ & $0-25$ & 15 & 22 \\
\hline 2 & Accept the lack of self to watch out for & $0-25$ & 15 & 23 \\
\hline 3 & $\begin{array}{l}\text { Accept themselves as wives and as citizens who have the right to become or not } \\
\text { become a candidate for the village head }\end{array}$ & $0-25$ & 15 & 21 \\
\hline \multirow[t]{3}{*}{4} & Understand the opportunities that need to be followed and strived to get opportunities & $0-25$ & 11 & 22 \\
\hline & Total scoring $/ \sum$ & 100 & 56 & 88 \\
\hline & Scoring of Decision Making & & & \\
\hline 1 & Understanding of the opportunities available, self-analysis & $0-25$ & 15 & 23 \\
\hline 2 & Courage to take chances to be candidate of head village when and how & $0-25$ & 15 & 23 \\
\hline 3 & Register and prepare the requirements needed to become candidates for village heads & $0-25$ & 15 & 24 \\
\hline \multirow[t]{3}{*}{4} & Decided to go ahead in the fight for the chair of the village head & $0-25$ & 15 & 21 \\
\hline & Total scoring $/ \sum$ & 100 & 60 & 91 \\
\hline & Scoring Directing According Decision Making & & & \\
\hline 1 & Preparing all the necessary requirements though & $0-25$ & 15 & 23 \\
\hline 2 & Physical and psychological preparation to face the opponent's competition & $0-25$ & 12 & 22 \\
\hline 3 & Division of time between competition needs and family needs & $0-25$ & 10 & 22 \\
\hline \multirow[t]{2}{*}{4} & Choosing the time to register as a candidate for the village head & $0-25$ & 10 & 22 \\
\hline & Total scoring $/ \sum$ & 100 & 47 & 89 \\
\hline
\end{tabular}




\begin{tabular}{lllll}
\hline Scoring of Actualization Decision and Risk of Decision Making & & & \\
\hline 1 & Submission of registration documents for candidates for village heads & $0-25$ & 10 & 20 \\
2 & Readiness to lose names, revile, shame, when someone loses in the election & $0-25$ & 11 & 21 \\
3 & Readiness to run out of property when someone loses in the election & $0-25$ & 12 & 24 \\
4 & $\begin{array}{l}\text { Analyzing the facts of the risk of someone who are losing the election: going crazy, } \\
\text { stress, suicide and others }\end{array}$ & $0-25$ & 12 & 24 \\
\hline & & & \\
\hline
\end{tabular}

In addition to scoring the decision making of research, scoring was also carried out on aspects that were quite influential in the success or failure of a person undergoing village head elections namely gender, finacial, praying, people and spiritual.

Table 6

Value of Readiness to Follow the Head Election: Before and After SGCP

\begin{tabular}{llll}
\hline Aspect of Readiness & Value & \multicolumn{2}{l}{ Value category } \\
\hline Gender & $10-100$ & $10-50$ & bad \\
Financial & $10-100$ & $51-70$ & good \\
Praying & $10-100$ & $71-100$ & very good \\
People & $10-100$ & & \\
Spiritual & $10-100$ & & \\
\hline
\end{tabular}

Table 7

Scores before and after the SGCP treatment

\begin{tabular}{|c|c|c|c|c|}
\hline \multicolumn{2}{|c|}{ No Indicator } & Score & \multirow[t]{2}{*}{$\begin{array}{l}\text { Before } \\
\text { SGCP }\end{array}$} & \multirow[t]{2}{*}{$\begin{array}{l}\text { After } \\
\text { SGCP }\end{array}$} \\
\hline & Scoring of Gender & & & \\
\hline 1 & Understand that her candidacy is as a representation of women & $0-25$ & 15 & 21 \\
\hline 2 & Understanding gender practical needs and striving for them to be met in government & $0-25$ & 10 & 21 \\
\hline 3 & $\begin{array}{l}\text { Understanding to be an obedient leader of the religious struggle of god and fulfill the command of } \\
\text { god }\end{array}$ & $0-25$ & 15 & 21 \\
\hline \multirow[t]{3}{*}{4} & Gender justice & $0-25$ & 10 & 22 \\
\hline & Total scoring $/ \sum$ & 100 & 50 & 85 \\
\hline & Scoring of Financial & & & \\
\hline 1 & Understand the family's own financial position & $0-25$ & 13 & 22 \\
\hline 2 & Understand and predict financial needs in village head elections & $0-25$ & 12 & 22 \\
\hline 3 & $\begin{array}{l}\text { Decide on the amount of money, the amount of money needed and find a way to choose to } \\
\text { prepare some money to prepare to become a candidate for the village head }\end{array}$ & $0-25$ & 13 & 22 \\
\hline \multirow[t]{3}{*}{4} & $\begin{array}{l}\text { understanding of the prediction and distribution of Sadaqah to citizens and rectifying one's } \\
\text { intention to spend money }\end{array}$ & $0-25$ & 12 & 24 \\
\hline & Total scoring $/ \sum$ & 100 & 50 & 90 \\
\hline & Scoring of Kiyai & & & \\
\hline 1 & $\begin{array}{l}\text { Understanding the need for support and whether a Kiyai or cleric when someone chooses to run in } \\
\text { the village head election }\end{array}$ & $0-25$ & 12 & 22 \\
\hline 2 & Choose Kiyai who need to be met and needed prayers for the success of being the village head & $0-25$ & 12 & 23 \\
\hline 3 & Follow the Kiyai to read a number of wired in a certain amount of time & $0-25$ & 13 & 22 \\
\hline \multirow[t]{3}{*}{4} & Reading wired for psychic strengthening confronts the challenge in running for village head & $0-25$ & 13 & 23 \\
\hline & Total scoring $/ \sum$ & 100 & 50 & 90 \\
\hline & Scoring of Praying & & & \\
\hline 1 & Confirmed the five daily prayers and the qabliyah wa ba'diyah prayer & $0-25$ & 11 & 22 \\
\hline 2 & Perform certain prayers to ask God to reduce the people's affection to choose & $0-25$ & 13 & 22 \\
\hline 3 & Praying hajat and praying tasbih & $0-25$ & 13 & 23 \\
\hline \multirow[t]{3}{*}{4} & Understand the conditions of faith and self-worship as an attempt to win a village head & $0-25$ & 13 & 23 \\
\hline & Total scoring $/ \sum$ & 100 & 50 & 90 \\
\hline & Scoring of People & & & \\
\hline 1 & Key people mapping that really gives a choice & $0-25$ & 13 & 23 \\
\hline 2 & Reduce support selection errors & $0-25$ & 12 & 23 \\
\hline 3 & Calculates the number of supporting estimates and supporting loss estimates & $0-25$ & 12 & 23 \\
\hline \multirow[t]{2}{*}{4} & $\begin{array}{l}\text { Calculates the number of supporting estimates and estimates of loss of supporters and support } \\
\text { money }\end{array}$ & $0-25$ & 13 & 21 \\
\hline & Total scoring $/ \sum$ & 100 & 50 & 90 \\
\hline
\end{tabular}




\begin{tabular}{|c|c|c|c|}
\hline Scoring of Spiritual & & & \\
\hline Seek and find spiritual support & $0-25$ & 15 & 23 \\
\hline Use of rings, keris, salt that have been given prayers only as a tool & $0-25$ & 10 & 20 \\
\hline Only believe in God who answers all prayers & $0-25$ & 15 & 22 \\
\hline Spiritual is a supporting tool for winning the village head candidate & $0-25$ & 10 & 20 \\
\hline Total scoring $/ \sum$ & 100 & 40 & 85 \\
\hline
\end{tabular}

\section{Observation}

As for the method used by researchers' observations for knowing the spiritual was doing by adult education. Observation conducted completes the expression expressed by the research subject, whether in the form of words, thoughts conveyed while the treatment is in progress. Beside that the researcher the researcher gives a score before and after treatment in the table that has been prepared by the researcher to assess all the processes that occur in the research subjects both before and after the SGCP according to the conditions of the research subjects.

\section{Documentation}

Documentation data in the form of photos of village heads, and sound recordings of research subjects during SGCP treatment were carried out in this study. Documentation data on prospective village heads and becoming village heads, and all documentation is supporting research as for the SGCP process, recording communication between research subjects and Kyai was documented as important in this study. The documentation instrument comes from a cellphone that records from recording and camera from all data and supports the results of research. Documentation was carried out in this study to achieve how decision-making skills were achieved and the SGCP process.

\section{Analysis of the Data}

Data analysis in the form of an assessment of the results of the SGCP by giving the achievement score in question, behaviour observed before the village head election, during and after the village head election as in Chart 2. The assessment's also given to the research subject for all behaviours, words that indicate the subject research fulfils decision-making skills as described in Chart 1 before, during and after village head elections. Analysis of SGCP education achievements to women can be observed from the behaviour of female village head candidates, changes in behaviour. Women's spirituality's measured from any prayer done to prepare to become the village head, wirid and the number of wirid which is read every day before the election time until the village head election. Interpreting differences before and after SGCP in this research according to table of measurenment was be done in this reseach. As for assessing skills in decision making, it can be observed from the words, attitudes, behaviours that women convey to researchers. Skills hat was achieved by women who become political representatives. Everything that as a woman she must be prepared to fight politically with male political representatives. Recording, sharing and storing data (Creswell, 2003) was be done in this research. Analysis data was be done likes Figure 6. 


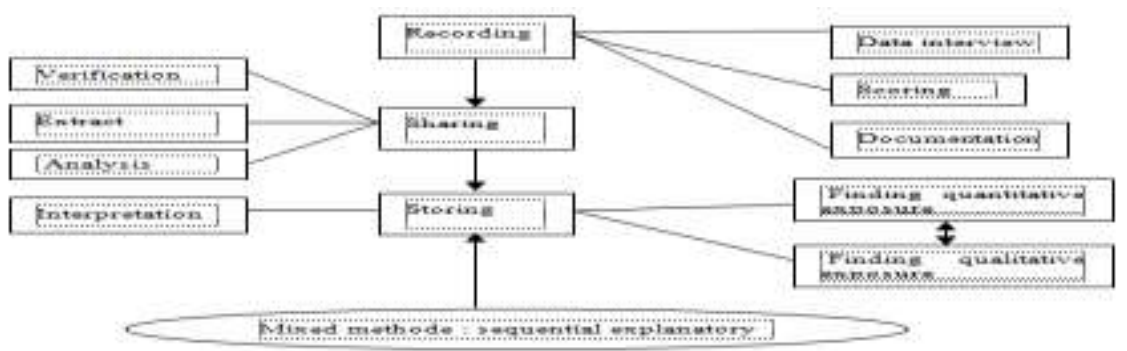

Figure 6

An Analysis in Step of Mix Method

\section{FINDINGS}

The spiritual of the guidance counselling for the politic (SGCP) that're done to the woman as treatment has shown Table 6.

Table 8

The Process of Education Woman's Politic as the Candidate of the Village Head: SGCP

\begin{tabular}{|c|c|c|c|}
\hline Phase & The activity of SGCP & The target of period change & Period \\
\hline $\begin{array}{l}\text { Understanding of woman's } \\
\text { political position }\end{array}$ & $\begin{array}{l}\text { 1. Discussing the significance of self- } \\
\text { understanding as the woman } \\
\text { representative in the general election of } \\
\text { the village head and the understanding } \\
\text { of gender disparity issue, the need of } \\
\text { having the man's gender characteristics } \\
\text { in leading the people. }\end{array}$ & $\begin{array}{l}\text { 1. Self-understanding as the } \\
\text { woman's representation in the } \\
\text { general election of the village head } \\
\text { and the understanding of gender } \\
\text { disparity issue and building the self- } \\
\text { power to be equal with the man's in } \\
\text { leading the people. }\end{array}$ & $\begin{array}{l}\text { The week of } \\
\text { strengthening the } \\
\text { personality }\end{array}$ \\
\hline $\begin{array}{l}\text { The acceptance and political } \\
\text { decision making of woman }\end{array}$ & $\begin{array}{l}\text { 2. Analyzing the self-power goodness } \\
\text { and weakness }\end{array}$ & $\begin{array}{l}\text { 2. Finding the self-characteristics as } \\
\text { the power to lead people in the } \\
\text { village }\end{array}$ & $\begin{array}{l}\text { The weeks of } \\
\text { accepting the self- } \\
\text { condition }\end{array}$ \\
\hline $\begin{array}{l}\text { Self-orientation in } \\
\text { accordance with the decision }\end{array}$ & $\begin{array}{l}\text { 3. Finding the supporting, economic, } \\
\text { spiritual, people, praying and } \\
\text { supranatural figure in succeeding the } \\
\text { general election of the village head }\end{array}$ & $\begin{array}{l}\text { 3. Self-orientation to the } \\
\text { supporting, economic, spiritual } \\
\text { power as the asset in the general } \\
\text { election of the village head }\end{array}$ & $\begin{array}{l}\text { The weeks of } \\
\text { mapping the } \\
\text { potential of } \\
\text { supporting, } \\
\text { economic, } \\
\text { spiritual, and } \\
\text { preternatural } \\
\text { power }\end{array}$ \\
\hline $\begin{array}{l}\text { Self-actualization and } \\
\text { understanding of the risk of } \\
\text { decided choice to be a } \\
\text { contestant in the general } \\
\text { election of the village head }\end{array}$ & $\begin{array}{l}\text { 4. Preparing the risk factors of being } \\
\text { failed in the election of the village head }\end{array}$ & $\begin{array}{l}\text { 4. self-preparation to release all } \\
\text { risks of losing the economic } \\
\text { support or capital spent for the } \\
\text { election of village head }\end{array}$ & $\begin{array}{l}\text { The weeks of } \\
\text { accepting the } \\
\text { results of the } \\
\text { general election }\end{array}$ \\
\hline
\end{tabular}

First finding: women as candidate village head can make decision to become a village head.

As for the interview results interview related to treatment which shows that the subject has made a decision, experienced treatment, experienced a change in behavior, and words that indicate the behavior are as follows. 


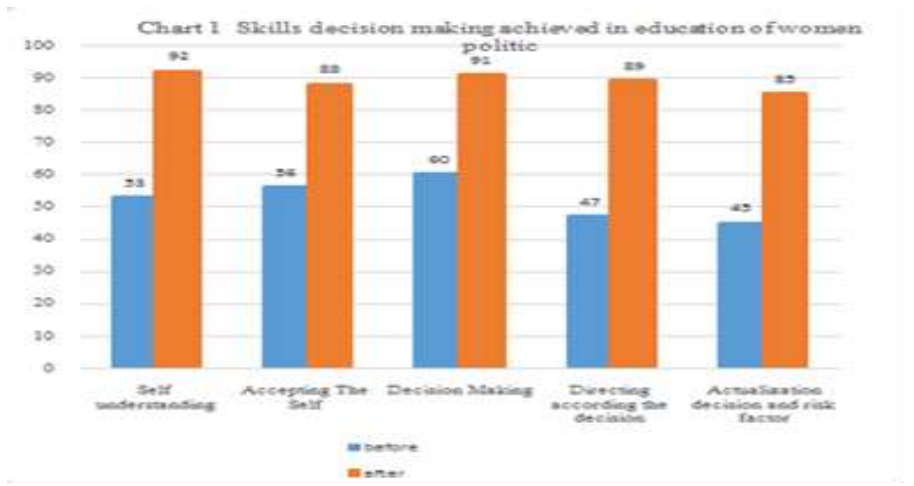

Figure 7

Explain

Table 7

Subject Statement Expression of Decision Making

\begin{tabular}{|c|c|c|}
\hline $\begin{array}{l}\text { Aspect of decision } \\
\text { making }\end{array}$ & Subject statement expression on discussion & Code \\
\hline Understanding & $\begin{array}{l}\text { "I knew there was an opportunity to become a village head. I am a woman and I understand } \\
\text { that I will follow the election of the village head, and I compete with male candidates " and "I } \\
\text { intend to fight in the path of God if I am elected and want to pay attention to the needs of } \\
\text { women because the of female voters was greater than male voters. but I still maintain gender } \\
\text { equality. and I am a female representative" }\end{array}$ & WAD 1 \\
\hline The acceptance & "even though I am a woman, I will dare to compete with men for the position of village head" & WAD 2 \\
\hline Decision making & $\begin{array}{l}\text { "I will make sure I take part in the village head election competition and my family also } \\
\text { supports my decision" }\end{array}$ & WAD 3 \\
\hline $\begin{array}{l}\text { Directing according } \\
\text { decision making }\end{array}$ & $\begin{array}{l}\text { "I will follow this opportunity. and I will collect the requirements needed to become the } \\
\text { village head" }\end{array}$ & WAD 4 \\
\hline $\begin{array}{l}\text { Actualling decision } \\
\text { and risk of decision }\end{array}$ & $\begin{array}{l}\text { "I will register according to the specified time after my file is complete" } \\
\text { "I became more aware and prepared myself that it was not always that the candidate } \\
\text { automatically became the village head. Even though they have used up all of their prayers, } \\
\text { finances, energy, thought, there are also those who commit suicide because of competition, } \\
\text { stress and having to find new jobs and become workers in foreign countries that is the risk of } \\
\text { joining the competition as village head." }\end{array}$ & WAD 5 \\
\hline
\end{tabular}

Second finding: implementation spiritual guidance counselling for politic (SGCP) among women adult education toward political decision making.

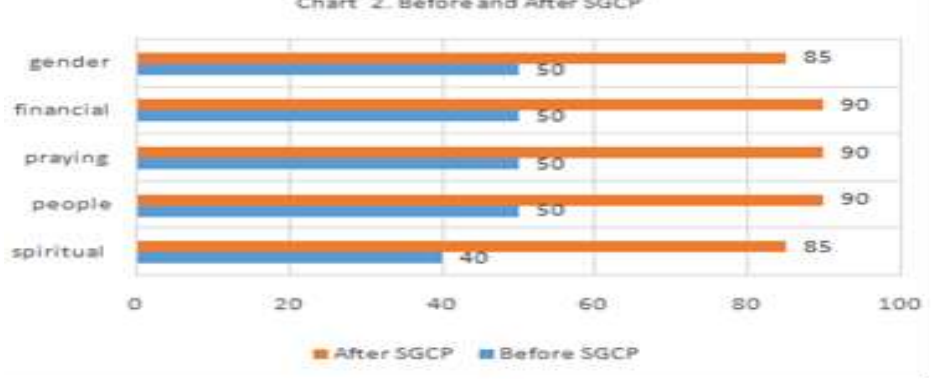

Figure 8

Explain

International Journal of Instruction, July $2020 \bullet$ Vol.13, No.3 
Table 8

Subject Statement Expression the Readiness to Follow the Head Election after SGCP

\begin{tabular}{|c|c|c|}
\hline Aspect & Subject statement expression after SGCP & Code \\
\hline Gender & $\begin{array}{l}\text { "If I later became the village head, I realized that I was a female representative, I knew } \\
\text { that not all women would get the opportunity like me, so I had to fight hard to direct all } \\
\text { my abilities. and I also keep balancing between my interests in my family as a wife, as } \\
\text { a mother and as a wife in my household" }\end{array}$ & WAD 8 \\
\hline Financial & $\begin{array}{l}\text { "based on sharing experiences with the instructor that I got now and hearing from the } \\
\text { experience of the previous female and male village heads, adequate financial } \\
\text { preparation is required to participate in the village head competition, I will try and be } \\
\text { supported by family support" }\end{array}$ & WAD 9 \\
\hline Praying & $\begin{array}{l}\text { "I realized that life was just living the destiny of God. But I must try as much as } \\
\text { possible to meet my needs through village head elections. Prayer and reading wired } \\
\text { according to instructions from the Kiyai become my strength to compete". }\end{array}$ & WAD 10 \\
\hline People & $\begin{array}{l}\text { "To be the village head I believe that I must have the support of the community. If no } \\
\text { one chooses I will not be the village head either. No matter how heavy my competition } \\
\text { is right now, I will fight with society seriously that I am better than a male candidate" }\end{array}$ & WAD 11 \\
\hline Spiritual & $\begin{array}{l}\text { "Based on Javanese tradition, anyone who will compete does indeed sometimes require } \\
\text { spiritual support. And I agree that the salt, water, rings, and keris that are given a } \\
\text { prayer can support the village head's competition. I agreed to live it and assisted by } \\
\text { several people so that the spiritual influence on my election became a village head" }\end{array}$ & WAD 12 \\
\hline
\end{tabular}

Spiritually have been done before election of candidate village head likes Figure 9.

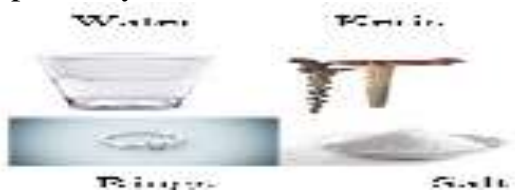

Figure 9

Illustrations of Water, Salt, Rings, Keris that have been Given the Prayer by Kiyai

Based on the finding of the average decision making and SGCP scores before and after treatment can be compared behavior changes based on the A-B-A design as in Figure.

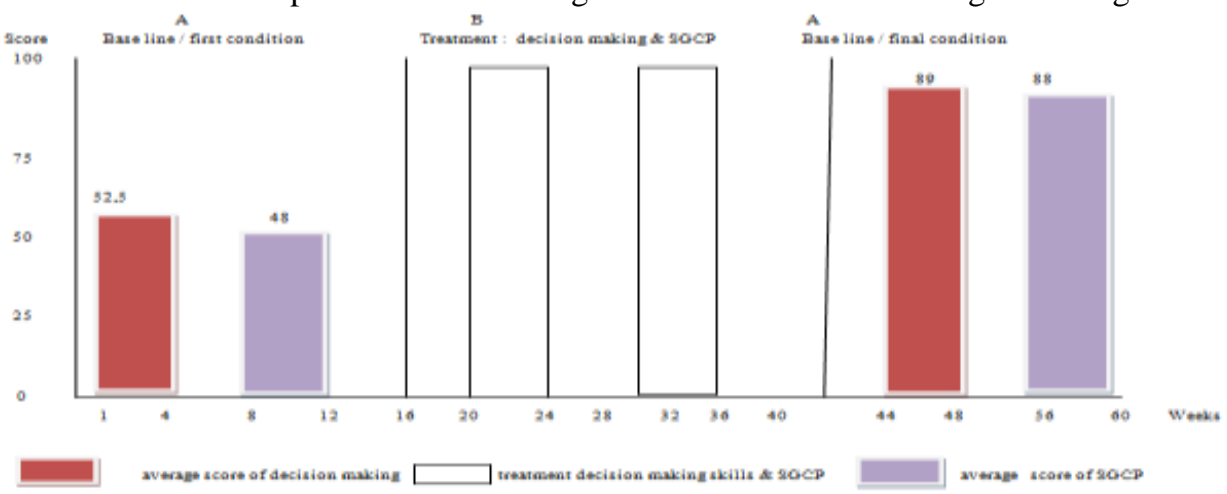

Figure 10

Average scores A-B-A

\section{DISCUSSION}

Women as subject research lead community groups around his residence well (Heidari, et.al, 2017) including everything even including people who're ill with religious 
practices will have a positive effect, especially in the interests of village head elections. Quran could improve the level of consciousness (Naseri-Salahshour, et.al, 2018) could strengthen the importance of the Quran for healthy people (Weiterbildung, 2018) while increasing family income. This political power needs psychological counselling (Goetzmann, et.al, 2006), psychosocial prosperity and the need of counselling during the procedure of evaluation showed that woman in politic that is struggling for the others women's need and developing themselves for life by guidance. Including family (Rodriguez, 2018) support for the choice of women to become village heads be special understanding of the woman's health related to the right and reproduction causes the low quality of woman's and child's life in the low level society. Therefore, the woman's representation in the politic expected could play the role of representation of women's needs that should be fulfilled through the woman's political (York, \& Bell, 2014) of representation (Sundstro, et.al, 2017).

SGCP could make someone more courageous in facing the real life (Ebrahimi, et.al, 2019) illustrates that a method that is applied to the subject of research will give the effect of changing certain thought patterns or behaviour patterns. Likewise with SGCP before and after SGCP grants there were changes or differences experienced by women who were trained (Wu, et.al, 2018) and educated before, during, and after women's political elections according to this study as in Chart 2. SGCP results are spiritually increasing in female research subjects. Spiritually is how someone has relationship with God and suggested that religious interventions (Naimi, et.al, 2019). With the increase in how far the practice of worship and self develops (Kazeminezhad, et.al, 2019) this corroborates research in this research believing the Quran as knowledge in the life.

People in Chart 2 referred to in this study are that to become village heads as political representatives' women need to get people support. For the people component, it could be assessed that before SGCP and after there were changes more people were predicted to choose this female representative in the village head election. As the research result, for the sake of faith, the faith's used in the SGCP process which can be used to be effectively. In Buddha religion that is used in the therapy for woman is relatively the Buddhist client's (Rungreangkulkij, \& Wongtakee, 2007). Moreover, in Islam teaching, the belief in Quran can be the power and guideline in running the life; in this case, the woman that be a contestant and selected with the highest number of votes with her male pair (620). She got 640 people and wins.

Praying in Chart 2 was experience (Sherman \& Webb, 2005) of the research subjects before SGCP there was no special wirid after SGCP conducted wirid with better indications of worship, the number of wirid read was more the better, both in number and quality (Naseri-Salahshour, et.al, 2018). Gender in Chart 2 shown that women as political representatives of women are expected to practical needs of women's gender and children and that it is expected in a policy. Spiritual, people, praying, economic, gender and readiness of all will make this woman elected as village head (Rosen, 2017) likes someone has a stronger propriety to be seeded (Prihatini, 2019). In Romania Belgium (Gârboni, 2014) the legislative background that's actually tightly applied and shifted in the public policy could contribute to the improvement of equal chance 
between woman. Meanwhile, spirituality (Naimi, et.al. 2019) has been defined as the faith and practice that develop based on the personal values and ideology of life meaning and goal referring to the belief that there are power and strength out of someone's self (Şimşir \& Boynueğri, 2017) that some individuals exhibited need religion and spirituality, the majority changes positively happen in spiritual life and spirituality for strengthening their faith. Adult education (Yau \& Mcnally, 2019) leads one to mature life like spiritual (Savickas, 2018) are a woman's choice according to her condition as comparative politics of gender (Krook, 2016). The finding of education of decision making skills shows that when women choose politics, women are ready with all the risks that women will receive. As for after being trained in decision-making skills, the researcher gave an assessment (Wu, et.al, 2018 ; Yau \& Mcnally, 2019). This is precisely as a lesson for adult education.

\section{CONCLUSION}

The strength of this research is that a person who has made a decision is held accountable and resolves their self what has become a decision. The key to adult education lies in this decision-making skill. Decisions taken will have a direct impact on individuals and this's very necessary for adult education. Adult education (Studies \& Bilgiler, 2019) will transmit the power to face all challenges to future generations with competition means also equip strong to face life's challenges depends on decisions (Leigh et.al., 2019) taken in life and consistency in the implementation of decisions. The weakness of this research's that not always accompanying women to become village heads or politics can win. Entering politics should not be a life-long job, because politics like a position is very limited, should provide work that is more oriented to one's talents or educational background (Prihatini, 2019). There are challenges when women have become party representatives or village heads in other countries (Biressi \& Nunn, 2017). May this be sacrifice for formulation adult education. In the effort to face the impact of political transition on the woman's participation to the decision making process, strengthening the political-based spiritual (Sajadi et al., 2018; Smith, 2017) counselling and communication (Dy-Boarman et.al, 2017) and making career decisions, becoming a village head is a good decision in career development for someone (Lee, 2018)

This research result recommends that when the women include in politic, they need political counselling that can help them to improve their courage to enter the political area. Their physical, psychological, economic, and spiritual preparations become the politic colour that should be completely owned by woman. (Wu, et.al, 2018). SGCP's needed to empowered and educated women become more powerful and employment for the representative women in politics. There're many behavioural changes after SGCP in psychological approach and the subject of research more better more motivate than before (Tappin, et.al 2019) every political research has a change in positive behaviour. Implication of this study's as psychological counseling model for adults in learning to enter politics and the challenges to be consistent with any risk taken by someone and avoid the stress of political consequences, and as a practical need for adult education. The contribution of this study's giving preparing for adult education to prepare adult education in strengthening decision making that has a great influence on one's life. 


\section{REFERENCES}

Ali A, Abdi, \& Dip, K. (2009). Global perspectives on adult education: An introduction. In A. A. Abdi, \& D. Kapoor (Eds.), Global perspectives on adult education (pp. 1-16). Springer. https://doi.org/10.1057/9780230617971.

Alsaba K., \& Kapilashrami, A. (2016). Understanding women 's experience of $\mathrm{v}$ iolence and the political economy o $f$ gender in conflict: The case of Syria. International Journal Reproductive Health and Matte, 24(47), 1-13. https://doi.org/10.1016/j.rhm.2016.05.002.

Barlow, H. D., \& Hersen, M. (1984). Single case experimental designs . Strategies for studying behavior change. New York : Pergamon Press.

Binod, M., Sundararajan, A., Lorn, J., \& Sheehan, S. M. (2013). Influencing group decisions by gaining respect of group members in e-learning and blended learning environments: a path model analysis. In M. . Khine (Ed.), Application of structural equation modeling in educational research and practice (pp. 241-255). Sense Publishers.

Biressi, A., \& Nunn, H. (2017). Transforming the politics of gender and voice: Strategies of expertise and experience. In S. R. Sans (Ed.), Representing communities (pp. 35-53). Palgrave Macmillan, Cham. https://doi.org/10.1007/978-3-319-65030-2_3.

Bruniges, M. (2007). Teacher professional judgement in teaching and learning decisions. In R. Maclean (Ed.), Learning and teaching for the twenty-first century: 233 festschrift for professor Phillip Hughes (pp. 233-254). Springer.

Bullough, A. Kroeck, G. K., Kundu, K. S., Lowe, B. H. K., \& Lowe, B. K. (2012). Women's political leadership participation around the world: An institutional analysis. Journal International of The Leadership Quarterly, 23(3), 398-411. https://doi.org/10.1016/j.leaqua.2011.09.010. 1048-9843/

Celis, K. (2013). Representativity in times of diversity: the political representation of women. Journal International of Women's Studies International Forum, 41, 179- 186. https://doi.org/1 0.1016/j.wsif.2013.07.007.

Cremer, D. De. (2013). The proactive leader how to overcome procastination and be a bold desicion maker. China: China europe international business school.

Creswell J., \& Wisdom J. W. (2013). Mixed methods: Integrating quantitative and qualitative data collection and analysis while studying patient-centered medical home models. Retrieved from AHRQ Publication No. 13-0028-EF

Creswell J. (2014). Reseach design: Qualitative, quantitative, mixed methodes approaches. California: Sage Publishing.

Cross, A. F., \& Conn-Powers, M. (2013). Making the intentional decision to use an effective curriculum to promote children's learning. Early Childhood Educ J, 42, 1-10. https://doi.org/10.1007/s10643-013-0623-4.

Dameron, M. L., Foxx, S. P., \& Flowers, C. (2019). The impact of race, gender , and socioeconomic status on school counselors' alternative learning program placement decisions: An experimental study. The Urban Review, 51, 599-723. 
https://doi.org/10.1007/s11256-019-00502-9.

Dy-Boarman, E. A., Nisly, S. A., \& Martin, D. (2017). Use of a health screening and education event to change student attitudes toward the elderly. Currents in Pharmacy Teaching and Learning, 9(1), 101-107. https://doi.org/https://doi.org/10.1016/j.cptl.2016.08.041.

Ebrahimi, M. R., Morteza, S., Toroujeni, H., \& Shahbazi, V. (2019). Score equivalence, gender difference, and testing mode preference in a comparative study between computer-based testing and paper-based testing. Int Journal of Emerging Technologies in Learning, 14(7), 128-143. https://doi.org/https://doi.org/10.3991/ijet.v14i07.10175.

Formenti, L., \& West, L. (2018). Transforming perspectives in lifelong learning and d adult education a dialogue. Palgrave Macmillan, Cham. https://doi.org/10.1007/978-3319-96388-4

Gârboni, S. (2014). Women in politics during the romanian transition. Procedia - Social and Behavioral Sciences, 163, 247-256. https://doi.org/10.1007/978-3-662-53637-7_7.

Ghani, E., Kerr, R. W., \& O'Connel. D. S. (2014). Political reservations and women's entrepreneurship in India. International Journal of Development Economics, 41, 179- 186.

Goetzmann, L., Goetzmann, L., Huber L. W., Klaghofer, R., Muellhaupt, B., Clavien P. A., Buddeberg, C., \& Scheuer, E. (2006). Psychosocial well-being and need for counselling during the evaluation procedure. Transplantation Proceedings, 38, 29312936. https://doi.org/doi:10.1016/j.transproceed.2006.08.1712931-2936.

Grünenfelder, J. (2013). Discourses of gender identities and gender roles in Pakistan: women and non-domestic work in political representations. International Journal of Women's Studies International Forum, 40, 68-77. https://doi.org/.http://dx.doi.org/1 0.1016/j.wsif.2013.05.007. 0277-5395.

Heidari, S., Rezaei, M., Sajadi, M., Ajorpaz, N. M., \& Koenig, H. G. (2017). Religious practices and self-care in iranian patients with type 2 diabetes. Journal of Religion and Health, 56(2), 683-696. https://doi.org/https://doi.org/10.1007/s10943-016-0320-x.

Jacobs D., Paxton, M. P., \& Jackson, L. A., (2013). Murder, political resources, and women's political success. International Journal of Social Science Research., 27, 105115. https://doi.org/doi:10.1016/j.electstud.2007.11.009. 0261-3794.

Jeong, S. Y., \& Kim, O. H. (2016). North Korean women defectors in South Korea and their political participation. International Journal of Intercultural Relations, 55, 20-31. https://doi.org/http://dx.doi.org/10.1016/j.ssresearch.2012.09.00.

Jiang, Y. (2017). A study on professional development of teachers of English as a foreign language in institutions of higher education in Western China. Berlin, Heidelberg: Springer. https://doi.org/10.1007/978-3-662-53637-7_7.

Karp A. S., \& Banducci, A. J. (2008). When politics is not just a man's game: Women'srepresentation and political engagement. Electoral Studies, 27, 105-115. https://doi.org/:10.1016/j.electstud.2007.11.009.

Kazeminezhad, B., Tarjoman, A., \& Borji, M. (2019). Relationship between praying 
and self-care in elderly with heart failure: A cross-sectional study in West of Iran. $J$ of Religion and Health, 59, 19-28. https://doi.org/10.1007/s10943-018-00757-8.

Koyuncu, L. B., \& Sumbas. A. (2016). Discussing women's representation in local politics in Turkey: The case offemalemayorship. International Journal of Women's Studies International Forum, 58, 41-50. https://doi.org/.http://dx.doi.org/10.1016/j.wsif.2016.06.003.

Krook, M. L. (2016). Gender quotas and comparative politics gender quotas and comparative politics: Past, present, and future research agendas. Politics \& Gender, 9, 299-328. https://doi.org/https://doi.org/10.1017/S1743923X13000160.

Langdon, A. J., Song, M., \& Niv, Y. (2019). Uncovering the 'state': Tracing the hidden state representations that structure learning and decision-making. Behavioural Processes, 167, 1-18. https://doi.org/10.1016/j.beproc.2019.103891.

Lee, N. K. K. (2018). The effect of internal locus of control on career adaptability: the mediating role of career decision, making self-efficacy and occupational engagement. Journal of Employment Counseling, 55(1), 2-15. https://doi.org/10.1002/joec.12069

McVey, M. (2017). Global networks, local action: Rethinking adult education policy in the $21 \mathrm{st}$ century. International Review of Education, 64, 1-3. https://doi.org/10.1007/s11159-017-9669-7.

Mendelberg, T., \& Karpowitz F. C. (2016). Women's, authority in political decisionmaking groups. International Journal of the Leadership Quarterly, 27, 487-503. https://doi.org/http://dx.doi.org/10.1016/j.leaqua.2015.11.005.

Msiska, F. G. W. (2018). Policy making in adult education: A comparative approach across 21 European regions. International Review of Education, 65, 187-190. https://doi.org/10.1007/s11159-018-9750-x.

Naimi, E., Babuei, A., Moslemirad, M., Rezaei, K., \& Eilami, O. (2019). The effect of spirituality intervention on the anxiety parents of hospitalized newborns in a neonatal department. Journal of Religion and Health, 1-8. https://doi.org/10.1007/s10943-01800753-y.

Naseri-Salahshour, V., Varaei, S., Sajadi, M., Tajdari, S., Sabzaligol, M., \& Fayazi, N. (2018). The effect of religious intervention on the level of consciousness of comatose patients hospitalized in an intensive care unit: a randomized clinical trial. European Journal of Integrative Medicine, $21, \quad 53-57$. https://doi.org/https://doi.org/10.1016/j.eujim.2018.06.008.

Nobles, J., Brown, R., \& Catalono, R. (2010). National independence, women's political participation, and life expectancy in Norway. Journal International of Sosial Science \& Medicine, 70, 1350-1357. https://doi.org/doi:10.1016/j.socscimed.2009.12.0120277-9536.

Paudel, Y., \&, Araujo. D. P. (2016). Demographic responses to a political transformation: Evidence of women empowerment from Nepal. International Journal of Comparative Economics, 45(2), 325-343. https://doi.org/doi:10.1016/j.jce.2016.07.003.

Prihatini, E. S. (2019). Women who win in Indonesia: the impact of age, experience, 
and list position. Women's Studies International Forum, 72, 40-46. https://doi.org/https://doi.org/10.1016/j.wsif.2018.10.003.

Pruysers, S., \& Blais, J. (2014). Anything women can do men can do better: an experiment examining the effects of stereotype threat on political knowledge and efficacy. The Social Science Journal, 51(3), 341-349. http://dx.doi.org/10.1016/j.soscij.2014.05.005.

Quamruzzaman, A., \& Lange, M. (2016). Female politic al representation and child health: evidence from amultilevel analysis. International Journal of Social Science \& Medicine, 171, 48-57. http://dx.doi.org/10.1016/j.socscimed.2016.10.0250277-9536.

Ragin, C. C. (2014). The comparative method moving beyond qualitative and quantitative strategies. Oakland, California : University of California Press.

Rogers, A. (2017). International perspectives on older adult education: Research, policies and practice. International Review of Education, 63(2), 285-287. https://doi.org/10.1007/s11159-016-9601-6.

Rosen, J. (2017). Gender quotas for women in national politics: a comparative analysis across development thresholds. Social Science Research, 66, 82-101. https://doi.org/https://doi.org/10.1016/j.ssresearch.2017.01.008.

Rungreangkulkij, S., \& Wongtakee, W. (2007). The psychological impact of buddhist counseling for patients suffering from symptoms of anxiety. Archives of Psychiatric Nursing, 22, 127-134. https://doi.org/doi:10.1016/j.apnu.2007.07.004.

Sajadi, M., Niazi, M., Khosravi S., Yaghobi, A, \& Rezaei, M., K. G. H. (2018). Effect of spiritual counselling on spiritual well-being in Iranian women with cancer: A randomized clinical trial. Complementary Therapies in Clinical Practice, 30, 79-84. https://doi.org/https://doi.org/10.1016/j.ctcp.2017.12.011.

Sajadi, M., Niazi, N., Khosravi, S., Yaghobi, A., Rezaei, M., \& Koenig, H. G. (2018). Effect of spiritual counselling on spiritual well-being in Iranian women with cancer: A randomized clinical trial. Complementary Therapies in Clinical Practice, 30, 79-84. https://doi.org/10.1016/j.ctcp.2017.12.011.

Sandu, A., \& Caras. A. (2014). Appreciative christian counseling. Procedia - Social and Behavioral Sciences, 128, 87-92. https://doi.org/10.1016/j.sbspro.2014.03.123. 1877-0428.

Savickas, S. (2018). Review of career development \& planning: a comprehensive approach. Journal of Employment Counseling, 55(1), 41-43. https://doi.org/https://doi.org/10.1002/joec.12072.

Setiawan, A., Agiwahyuanto, F., \& Arsiwi, P. (2019). A virtual reality teaching simulation for exercise during pregnancy. International Journal of Emerging Technologies in Learning, 14(1), 34. https://doi.org/10.3991/ijet.v14i01.8944.

Sherman, R. R. \& Webb. B. (2005). Qualitative research in education: Focus and methods. London and New York: Roudledge Falmer.

Şimşir Z., \& Boynueğri T. S. D. B. (2017). Religion and spirituality in the life of individuals with paraplegia: spiritual journey from trauma to spiritual development. International Journal Of Spiritual Psychology And Counselling, 1, 89-110. 
https://doi.org/DOI10.12738/spc.2017.1.00232.

Smith, K. (2017). Teachers as self-directed learners. Springer. https://doi.org/10.1007/978-981-10-3587-6_9

Spicer. Z., McGregor M. A., \& Alcantara, C. (2017). Political opportunity structures and the representation of women and visible minoritiesin municipal elections. International Electoral Studies, 48, 10-18. https://doi.org/10.1016/j.electstud.2017.01.002.

Seawright, J. (2016). Strategies for social inquiry, multi-method social science: Combining qualitative and quantitative tools. Northwestern University, Illinois : Cambridge, University press.

Baidi, B. (2019). The role of parents' interests and attitudes in motivating them to homeschool their children. Journal of Social Studies Education Research, 10(1), 156-177.

Sundström, A., Paxton, P., Wang Y-T., \& Lindberg, I. (2017). Women's political empowerment: A new global index, 1900-2012. World Development, 94, 321-335. http://dx.doi.org/10.1016/j.worlddev.2017.01.016.

Tappin, B. M., McKay, R. T., \& McKay, R. T. (2019). Moral polarization and out-party hostility in the US political context. Journal of Social and Political Psychology, 7(1), 213-245. https://doi.org/10.5964/jspp.v7i1.1090.

Vela, J. C., Sparrow, G: S., Whittenberg, J. F., \& Rodriguez, B. (2018). The role of character strengths and importance of family on mexican american college students' career decision self-efficacy. Journal of Employment Counseling, 55(1), 16-28. https://doi.org/10.1002/joec.12070.

Nhi. V. N. Y., Xuezhong, H., Shaowu, L., \& Guandong, X. (2019). Deep learning for decision making and the optimizationof socially responsible investments and portfolio, decision support systems. Decision Support Systems, 124, 1-42. https://doi.org/10.1016/j.dss.2019.113097.

Wu, Y. C., Wang, H. S., \& Shlley, T. C. (2018). The relation of career adaptability to work-family experience and personal growth initiative among Taiwanese working parents. Journal of Employment Counseling, 55(1), 27-40. https://doi.org/DOI: 10.1002/joec.12071.

Yang, K.-H. (2016). Participatory video in adult education. Springer. https://doi.org/10.1007/978-981-10-1050-7.

Yau, J. O., \& Mcnally, G. P. (2019). Science direct rules for aversive learning and decision-making. COBEHA, 26, 1-8. https://doi.org/10.1016/j.cobeha.2018.08.006.

York, R., \& Bell, E. S. (2014). Life satisfaction across nations: the effects of women's political status and public priorities. International Journal of Social Science Research, 48, 48-61. https://doi.org/10.1016/j. ssresearch.2014.05.004.

Zeuner, C. (2017). Comparative perspectives on theoretical frameworks of adult education. In A. Laros, T. Fuhr, \& E. W. Taylor (Eds.), Transformative learning meets bildung (p. 233-243.). Sense Publishers. 